DOI: 10.34015/2523-4552.2019.3.13

УДК 342.9 (477)

Василенко Я. М.,

здобувач Інституту права

та суспільних відносин Відкритого

міжнародного університету розвитку

людини «Україна»

e-mail: Vasylenko25@i.ua

ORCID ID: 0000-0003-1699-9704

\title{
СУТНІСТЬ ТА ОСОБЛИВОСТІ ВІДОМЧОГО КОНТРОЛЮ ЯК ОДНОГО З ЗАСОБІВ ЗАБЕЗПЕЧЕННЯ ЗАКОННОСТІ У СФЕРІ СУДОЧИНСТВА
}

У статті, на основі аналізу поглядів учених, а також норм чинного законодавства України, охарактеризовано сутність та особливості відомчого контролю за станом законності у сфері судочинства. Запропоновано напрямки удосконалення нормативно-правової бази, шляхом конкретного виділення та визначення сутності даного різновиду контролю та суб'єктів його реалізації.

Ключові слова: контроль; відомчий контроль; судочинство; забезпечення законності.

В статье на основе анализа научных взглядов ученых, а также норм действующего законодательства Украины, охарактеризованы сущность и особенности ведомственного контроля за состоянием законности в сфере судопроизводства. Предложены направления совершенствования нормативноправовой базы в данной области, путем конкретного выделения и определения в ней сущности данного вида контроля и субъектов его реализации.

Ключевые слова: контроль; ведомственный контроль; судопроизводство; обеспечение законности.

Постановка проблеми. Сучасна Україна - це демократична суверенна держава, яка знаходиться лише на початку свого розвитку, основою вектору якого, на сьогоднішній день, є забезпечення перейняття та імплементація європейських цінностей у всіх сферах життєдіяльності українського суспільства, а також високого рівня дотримання прав i свобод людини і громадина. Досягнення означених цілей покладається на розгалужену систему державного механізму, одним із важливих елементів якого $\epsilon$ судочинство. У державi, яка прагне стати правовою, судові інстанції повинні відігравати основоположну роль, бути авторитетним важелем захисту людських свобод, самостійним та, що найбільш головне, відповідним принципу законності у своїй діяльності.

Однак, попри всі реформаційні перетворення, які прямо торкнулись 
системи судочинства нашої держави, питання дотримання законності в роботі судів залишається актуальним. Сучасні виклики, що стоять перед Україною, вимагають ще глибшого, всеосяжного та ефективного контролю за роботою органів всіх трьох гілок державної влади. Не $є$ в даному аспекті виключення судочинство в рамках якого одним із дієвих засобів забезпечення законності $є$ спеціальний, відомчий контроль.

Аналіз останніх досліджень і публікацій. Теоретичним підгрунтям дослідження стали праці вчених, які присвячували свої наукові пошуки питанням сутності законності, її прояву та забезпеченню в роботі держави та судових органів. Так, загальнотеоретичні питання законності розглядалися в роботах учених галузевих юридичних наук: С. С. Алексєєва, Є. Ю. Бараша, М. В. Вітрука, Б. М. Габрічидзе, В. І. Євінтова, Р. А. Калюжного, М. І. Козюбри, В.П. Колісника, О. М. Музичука, С. В. Старжинського, Є. М. Старосцяка, Ю. М. Тодики, К. Б. Толкачова, Т. Л. Торсона, Ю. В. Трошкіна, А. Г. Хабібуліна, М. В. Цвіка, В. М. Шаповала, O. В.Шмоткіна та інших. Питання забезпечення законності в роботі органів державної влади, зокрема судовихорганыв, були предметом дослідження В. Б. Авер'янова, Є. В. Аграновської, В. Д. Бабкіна, Ю. М. Бисаги, С. В. Бобровник, В. М. Горшеньова, А. П. Заєць, О. В. Зайчука, В. К. Колпакова, Н. М. Оніщенко, O. В. Петришина, Н. С. Прозорова, П. М. Рабіновича, В. В. Самохвалова, В. Ф. Сіренка, О. Ф. Скакун, В. Д. Ткаченка, Р. О. Халфіна, Ю. С. Шемшученка. Проте, слід звернути увагу, що незважаючи на значний обсяг наукових напрацювань, проблема сутності та особливостей відомчого контролю, як одного із засобів забезпечення законності у сфері судочинства, належної уваги та розвідки не отримала.

Постановка завдання. Саме тому метою статті $\epsilon$ : вивчення i встановлення сутності та особливостей відомчого контролю, як одного із засобів забезпечення законності у сфері судочинства України.

Виклад основного матеріалу. На сьогоднішній день проблематика законності $\epsilon$ «наріжним каменем» будь-якої держави. 3 кожним роком забезпеченню даного аспекту в усіх сферах діяльності держави приділяється все більша увага, саме як основному правовому принципу, а не декларативній умові. Особливо гостро це питання постає у сфері функціонування судочинства України, адже високий рівень законності в середині ïi системи, прямо впливає на рівень забезпечення законності судами в рамках тих чи інших суспільних відносин. Але чим є законність та який ціннісний орієнтир вона несе?

3 приводу змісту принципу законності існують різні погляди. Наприклад, на думку В. В. Копейчикова, законність - це такий режим державного і суспільного життя, за якого забезпечується повне й неухильне дотримання i виконання законів, підзаконних актів усіма без винятку органами держави, громадськими організаціями, посадовими особами і громадянами. Поняття законності охоплює дотримання i виконання всієї системи нормативних актів держави. Дослідник підкреслює, що законність означає, що при здійсненні посадовими особами своїх владних функцій не має місця суб'єктивізму і сваволі, що ведеться 
рішуча боротьба із різного роду зловживаннями, фактами зневажання законів, порушенням прав і законних інтересів громадян, а також 3 неправомірною поведінкою громадян [1, c. $208 ; \quad 2, \quad$ c. $42-43]$. Як зазнача $\epsilon$ В. С. Афанасьєв, законність - це принцип, загальнообов'язкова вимога, метод, режим та стан неухильного дотримання, виконання i застосування законів і заснованих на них правових актів усіма учасниками суспільних відносин у всіх сферах життя. Закріплена законодавством вимога дотримуватись правових розпоряджень, звернення до всіх суб'єктів суспільних відносин потрібно вважати принципом. Прояв законності в конкретній поведінці (діяльності) суб'єктів робить законність методом і станом їх діяльності. Елементом режиму суспільного життя законність буде тоді, коли більшість учасників суспільних відносин дотримуються, виконують і правильно застосовують правові приписи. Усі аспекти законності знаходять прояв у правотворчості, й у всіх формах реалізації права [3, с. 25]. С. С. Алексєєв розглядає законність як «реальність права, таку реальність, коли його вимоги гарантовані можливістю послідовного, повного і неухильного втілення в життя». Він справедливо вважає, що поняття «законність» розкриває зміст правової дійсності, практичне здійснення правових норм, ідейно-політичних основ правової системи, її зв'язки з суспільно-політичними інститутами, 3 політичним режимом цього суспільства [4]. С. Ф. Денисюк переконаний, що законність - це атрибут існування і розвитку демократично організованого суспільства. Вона $\epsilon$ необхідною для забезпечення свобо- ди і реалізації прав громадян, здійснення демократії, функціонування громадянського суспільства, науково обгрунтованої побудови і раціональної діяльності державного апарату. Вона $\epsilon$ обов'язковою для всіх елементів державного механізму (державних органів, державних організацій, державних службовців), громадянського суспільства (суспільних, релігійних організацій, незалежних засобів масової інформації, неформальних об'єднань та ін.) і для всіх громадян [5, с. 37].

Тож, входячи із аналізу думок вчених законність - це принцип, який несе в собі ідею особливого правового порядку у державі, за якого усі суб'єкти, особливо органи державної влади, повинні в своїй діяльності неухильно дотримуватись норм законодавства. В такому форматі зміст даного принципу закріплено у Конституції України, де в статті 19 вказано, що органи державної влади та органи місцевого самоврядування, їх посадові особи зобов'язані діяти лише на підставі, в межах повноважень та у спосіб, що передбачені Конституцією та законами України [6].

Проектуючи побудовану теоретичну думку на сферу діяльності судочинства можна зробити висновок, що в ï рамках законність - це принцип роботи судів, за якого останні провадять свою діяльність виключно в межах та на підставі норм Конституції та дійсного законодавства України.

Відмітити варто, що на сьогоднішній день існують різні способи та засоби забезпечення законності $\mathrm{y}$ сфері судочинства, одним із яких $\epsilon$ відомчий контроль. В своєму класичному вигляді контроль постає уні- 
версальним інструментом перевірки та спрямування діяльності органів влади. Так, термін «контроль» (від французької - «controle») означає:

- перевірку, спостереження 3 метою перевірки;

- нагляд 3 метою перевірки, контроль над звітністю;

- перевірка, облік діяльності кого-, чого-небудь, нагляд за кимось, чимось;

- установа або організація, що здійснює нагляд за ким-, чим-небудь або перевіряє його тощо [7; 8; 9].

Отже, виходячи лише із етимології терміну «контроль» доходимо висновку, що він позначає процес перевірочної діяльності, направленої на визначення відповідності контрольованого об'єкту певним правилам, вимогам, закономірностям та недопущення їх порушень.

Відповідно до поглядів окремих науковців, наприклад, Н. В. Богданова, контроль - це спостереження за відповідністю діяльності об’єкта тим приписам, які він отримав від суб'єкта управління, та виконанням прийнятих рішень [10, с. 6]. Ученийправознавець Б. М. Лазарєв зазначає, що контроль - це функція, призначення якої полягає в тому, щоб встановити відповідність чи невідповідність фактичного стану та діяльності об'єктів, що управляються, заданому ïх стану. Він дозволяє знаходити та ліквідовувати відхилення об'єкта від заданого стану чи коректувати рішення, які були прийняті раніше [11, c. 134]. На думку Г. Г. Зуйкова, за допомогою контролю вирішуються наступні управлінські завдання: забезпечення неухильного виконання законів і нормативних актів, регламентуючих діяльність державних органів та інших об'єктів управління; досягнення своєрідності і якості виконання прийнятих рішень; підвищення виконавської дисципліни, відповідальності за доручену справу; своєчасне прийняття заходів до усунення виявлених в процесі контрою недоліків; виявлення передового досвіду і впровадження його в практику роботи; сприяння правильному підбору й розстановці кадрів, своєчасне попередження їх від помилок; здійснення необхідної допомоги підпорядкованим апаратам та працівникам [12, с. 155-156;13, с. 338].

Дещо інше тлумачення надають вчені при розгляді поняття «відомчий контроль». Так, О.Р. Михайленко відмічає, що відомчий контроль - це самостійний вид, форма державного контролю. Він складає невід'ємну частину діяльності компетентного органу по керівництву підлеглими і виконанню ними своїх завдань. У порівнянні з іншими видами контролю і нагляду відомчий має найбільші можливості по безпосередньому впливу на об'єкт, що перевіряється $[14$, с. 236]. А. А. Коваленко вказує на те, що відомчий контроль здійснюється на підприємствах, установах, організаціях контролюючим суб'єктом у відомчому підпорядкуванні якого вони знаходяться $[15$, с. 45]. Натомість, В. К. Колпаков стверджує, що відомчий контроль - це контроль, здійснюваний центральними органами державної виконавчої влади, їх структурними підрозділами стосовно організаційно підпорядкованих їм ланок [16, c. 774].

Тож, спираючись на численні наукові переконання щодо тлумачення терміну «контроль» та «відомчий контроль», ми побудували власний проміжний висновок. Відповідно 
до нього відомчий контроль законності у сфері судочинства - це система заходів та методів, направлених на аналіз та забезпечення чіткого дотримання органами правосуддя приписів Конституції та законодавства України при виконанні покладених на них функцій, який здійснюється в середині структури судочинства спеціально уповноваженими на його провадження органами. По суті, це контроль системи над системою.

Даний вид контролю має власне коло особливостей, які здебільшого пов'язано із аспектами його організації. Так, необхідно відмітити, що судоустрій України складають місцеві, апеляційні суди та Верховний Суд. Єдність системи судоустрою забезпечується: 1) єдиними засадами організації та діяльності судів; 2) єдиним статусом суддів; 3) обов'язковістю для всіх судів правил судочинства, визначених законом; 4) єдністю судової практики; 5) обов'язковістю виконання на території України судових рішень; 6) єдиним порядком організаційного забезпечення діяльності судів; 7) фінансуванням судів виключно 3 Державного бюджету України; 8) вирішенням питань внутрішньої діяльності судів органами суддівського самоврядування [17].

Організація системи судочинства, забезпечення належності її роботи, зокрема у питанні контролю за дотриманням принципу законності покладається одразу на декілька органів суддівського самоврядування. Відповідно до законодавства, для захисту професійних інтересів суддів та вирішення питань внутрішньої діяльності судів в Україні діє суддівське самоврядування - самостійне колективне вирішення зазначених питань суддями. Суддівське самоврядування є однією з гарантій забезпечення незалежності суддів. Діяльність органів суддівського самоврядування має сприяти створенню належних організаційних та інших умов для забезпечення нормальної діяльності судів і суддів, утверджувати незалежність суду, забезпечувати захист суддів від втручання в їхню діяльність, а також підвищувати рівень роботи з кадрами у системі судів [17].

Одним 3 ключових органів, на який безпосередньо покладається контроль законності у сфері судочинства $\epsilon$ Вища рада правосуддя. Остання є колегіальним, незалежним конституційним органом державної влади та суддівського врядування, який діє в Україні на постійній основі для забезпечення незалежності судової влади, її функціонування на засадах відповідальності, підзвітності перед суспільством, формування доброчесного та високопрофесійного корпусу суддів, додержання норм Конституції і законів України, а також професійної етики в діяльності суддів і прокурорів [18].

Також окремі контрольні функції в структурі судочинства покладаються на Раду суддів України вищий орган суддівського самоврядування, що діє як виконавчий орган з'їзду суддів України. Так, Рада суддів України: здійснює контроль за організацією діяльності судів, заслуховує з цих питань Голову Державної судової адміністрації України, його заступників, керівників структурних підрозділів і територіальних управлінь Державної судової адміністрації України; здійснює контроль за додержанням вимог законодавства щодо врегулювання конфлікту інтересів у 
діяльності суддів, Голови чи членів Вищої кваліфікаційної комісії суддів України, Голови Державної судової адміністрації України чи його заступників; приймає рішення про врегулювання реального чи потенційного конфлікту інтересів у діяльності зазначених осіб (у разі якщо такий конфлікт не може бути врегульований у порядку, визначеному процесуальним законом) [17].

Висновки. Отже, резюмуючи вищевикладене зауважимо, що відомчий контроль в системі судочинства займає важливе місце та є дієвим засобом забезпечення законності в судовій галузі, що обумовлено наступними особливостями:

- по-перше, цільовою орієнтованістю - відомчий контроль здійснюється спеціальною, внутрішньою системою відомств суддівського самоврядування, яким належить уся повнота функцій щодо організації судоустрою в країні;

- по-друге, поліаспектністю відомчий контроль законності в системі судочинства виражається у цілому комплексі функцій, направлених на забезпечення відповідності системи судочинства вимогам законодавства, зокрема в питаннях матеріального, фінансового забезпечення судів, належності роботи та поведінки суддів визначеним стандартам, законності процесу призначення суддів на посади тощо;

- по-третє, наявністю нормативно-правової бази, яка регламентує роботу органів суддівського самоврядування у тому числі в галузі забезпечення законності в системі судочинства.

У той же час, враховуючи виключну важливість питання забезпечення законності у сфері судочинства, доцільним стане систематизація норм, які регламентують відповідний відомчий контроль. Найбільш доречним стане окреме виділення на законодавчому рівні сутності, форм, суб'єктів та повноважень останніх щодо реалізації контролю законності в галузі судочинства, що підвищить рівень цілісності та дієвості даного засобу забезпечення відповідності функціонування судової гілки влади національним та міжнародним правовим стандартам.

\section{Список використаних джерел}

1. Копейчиков В. В. Загальна теорія держави і права. Київ : Юрінком Інтер, 1998. 320 c.

2. Козак О.С. Звільнення від кримінальної відповідальності : дис. ... канд. юрид. наук : 12.00.08 / Дніпропетровський державний університет внутрішніх справ. Дніпропетровськ, 2008. 228 с.

3. Афанасьев В.С. Обеспечение законности вопросы теории и практики (по материалам органов внутренних дел) : дисс. ... канд. юрид. наук. Москва, 1993. 223 с.

4. Алексеев С. С. Теория права. Москва : БЕК., 1994. 187 с.

5. Денисюк С. Ф. Громадський контроль за правоохоронною діяльністю в Україні: адміністративно-правові засади : дис. ... д-ра юрид. наук : 12.00 .07 / Дніпропетр. держ. ун-т внутр. справ. Дніпропетровськ. 2010. 393 с.

6. Конституція України: закон від 28.06.1996 №254к/96-ВР. Офіційний вісник України. 2010. №72/1. ст.15.

7. Білодід І.К. Словник української мови: в 11 томах. Том 4. Київ, 1973. 657 с. 
8. Ожегов С. И. Словарь русского языка; под ред. чл.-кор. АН СССР Н. Ю. Шведовой. 18-е изд., стереотип. Москва : Рус. яз., 1987. 797 с.

9. Краснолюбов I., Яковець I. Актуальні питання організації та здійснення громадського контролю за поведінкою осіб, умовно-достроково звільнених від відбування покарання. Вісник Національної академії прокуратури України. 2010. № 2. C. 74-79.

10. Богданов М. В. Организация и совершенствование контроля в органах внутренних дел : лекція. Ташкент : ТВШ МВД СССР, 1982. 35 с.

11. Лазарев Б. М. Компетенция органов управления Москва : Юридическая література, 1972. $280 \mathrm{c.}$

12. Научная организация управления органами внутренних дел / под ред. Г. Г. Зуйкова. Москва : Академия МВД СССР, 1984. 317 с.

13. Салманова О. Ю. Правові акти в управлінській діяльності Національної поліції України : дис. ... д-ра юрид. наук : 12.00.07 / Харківський національний університет внутрішніх справ. Харків, 2016. 455 с.

14. Михайленко А. Р. Расследование преступлений: законность и обеспечение прав граждан: научно-практ. изд. Киев : Юринком Интер, 1999. 448 с.

15. Коваленко А. А. Правові основи фінансового контролю в сфері місцевих фінансів : дис. ... канд. юрид. наук : 12.00.07 / Київський міжнародний університет. Київ, 2009. 218 c.

16. Колпаков В. К. Адміністративне право України: підручник. Київ : Юрінком Інтер, 1999. 736 c.

17. Про судоустрій і статус суддів: закон від 02.06.2016 №1402-VIII. Урядовий кур'єр. 2016. №162.

18. Про Вищу раду правосуддя: закон від 21.12.2016 №1798-VIII. Відомості Верховної Ради України. 2017. №7-8. ст. 50.

\section{References}

1. Kopejchikov, V. V. (1998). Zagalna teoriya derzhavi i prava. Kiyiv: Yurinkom Inter [in Ukrainian].

2. Kozak, O. S. (2008). Zvilnennya vid kriminalnoyi vidpovidalnosti (Dis. ... kand. yurid. nauk). Dnipropetrovskij derzhavnij universitet vnutrishnih sprav. Dnipropetrovsk [in Ukrainian].

3. Afanasev, B. C. (1993). Obespechenie zakonnosti voprosy teorii i praktiki (po materialam organov vnutrennih del) (Diss. ... kand. yurid. nauk). Moskva [in Russian].

4. Alekseev, S. S. (1994). Teoriya prava. Moskva : BEK [in Russian].

5. Denisyuk, S. F. (2010). Gromadskij kontrol za pravoohoronnoyu diyalnistyu $v$ Ukrayini: administrativno-pravovi zasadi (Dis. ... d-ra yurid. nauk) Dnipropetr. derzh. un-t vnutr. sprav. Dnipropetrovsk [in Ukrainian].

6. Bilodid, I. K. (1973). Slovnik ukrayinskoyi movi: v 11 t. T. 4. Kiyiv [in Ukrainian].

7. Ozhegov, S. I. (1987). Slovar russkogo yazyka. 18-e izd. Moskva: Rus. yaz. [in Russian].

8. Krasnolyubov, I., Yakovec I. (2010). Aktualni pitannya organizaciyi ta zdijsnennya gromadskogo kontrolyu za povedinkoyu osib, umovno-dostrokovo zvilnenih vid vidbuvannya pokarannya. Visnik Nacionalnoyi akademiyi prokuraturi Ukrayini, 2, 74-79 [in Ukrainian].

9. Bogdanov, M. V. (1982). Organizaciya i sovershenstvovanie kontrolya v organah vnutrennih del. Tashkent: TVSh MVD SSSR [in Russian].

10. Lazarev, B. M. (1972). Kompetenciya organov upravleniya. Moskva: Yuridicheskaya literatura [in Russian]. 
11. Zujkov, G. G. (Red). (1984). Nauchnaya organizaciya upravleniya organami vnutrennih del. Moskva: Akademiya MVD SSSR [in Russian].

12. Salmanova, O. Yu. (2016). Pravovi akti v upravlinskij diyalnosti Nacionalnoyi policiyi Ukrayini. (Dis. ... d-ra yurid. nauk). Harkivskij nacionalnij universitet vnutrishnih sprav. Harkiv [in Ukrainian].

13. Mihajlenko, A. R. (1999). Rassledovanie prestuplenij: zakonnost i obespechenie prav grazhdan. Kiev: Yurinkom Inter [in Russian].

14. Kovalenko, A. A. (2009). Pravovi osnovi finansovogo kontrolyu v sferi miscevih finansiv (Dis. ... kand. yurid. nauk). Kiyivskij mizhnarodnij universitet. Kiyiv [in Ukrainian]. Ukrainian].

15. Kolpakov, V. K. (1999). Administrativne pravo Ukrayini. Kiyiv: Yurinkom Inter [in

Ya. Vasylenko, Postgraduate Student of the Open International University of Human Development «Ukraine»

e-mail: Vasylenko25@i.ua; ORCID ID: 0000-0003-1699-9704

\section{The nature and characteristics of departmental control as a means of ensuring legality in judicial proceedings}

In the article, based on the analysis of scientific views of scientists, as well as norms of the current legislation of Ukraine, the essence of departmental control over the state of law in the sphere of justice is described. It is determined that the departmental control of legality in the field of justice is a system of special measures and methods aimed at analyzing and ensuring the strict observance of the norms of the Constitution and the current legislation of Ukraine when performing the functions assigned to them, which is implemented in the middle of the structure of the judiciary by specially authorized bodies.

It is stated that in the field of justice, lawfulness is a special principle of functioning of the judicial bodies of Ukraine, under which the latter conduct their activity solely within the limits and on the basis of the norms of the Constitution and actual legislation of Ukraine.

The key features of departmental control are described as a means of ensuring lawfulness in the field of justice, which include: target orientation, poly-aspect, the existence of a sound regulatory framework.

The directions of improvement of the regulatory framework in this field are proposed, by specific selection and definition in it of the given type of control and subjects of its implementation.

Keywords: control; departmental control; justice; assurance of legality. 